\title{
EFFECTS OF INSULIN AND EMBRYONIC STEM CELLS LOADED PLGA NANOPARTICLES ON PANCREATIC BETA TC CELLS
}

\author{
ÇIĞDEM YÜCEL ${ }^{1}$, YEŞIM AKTAŞ', ZELIHAGÜL DEĞIM²*, ŞÜKRAN YILMAZ ${ }^{3}$, TAIBE ARSOY ${ }^{3}$, \\ LEVENT ALTINTAŞ ${ }^{4}$, CAN ÇOKÇALIŞKAN ${ }^{3}$ and MAHMUT SÖZMEN ${ }^{5}$
}

\author{
'Department of Pharmaceutical Technology, Erciyes University Faculty of Pharmacy, \\ Kayseri, Turkey \\ ${ }^{2}$ Department of Pharmaceutical Technology, Biruni University Faculty of Pharmacy, \\ İstanbul, Turkey \\ ${ }^{3}$ Food and Mouth Diseases Institute, Ankara, Turkey \\ ${ }^{4}$ Department of Pharmacology and Toxicology, \\ Ankara University Faculty of Veterinary Medicine, Ankara, Turkey \\ ${ }^{5}$ Department of Pathology, 19 Mayıs University Faculty of Veterinary Medicine, \\ Samsun, Turkey
}

\begin{abstract}
The present study, aims to investigate and compare the effect of insulin and embryonic stem cells (ESC) loaded nanoparticle formulations (NPs) on pancreatic-beta-TC-cell regeneration. Characterization studies of NPs were performed. Permeability of insulin and the effect of ESC on pancreatic beta cells were investigated. Insulin or glucose levels were determined and histologic investigations were also performed. ESC encapsulation efficiency was calculated by western blot analysis. The particle sizes of insulin and ESC-loadedNPs were determined as $0.665 \pm 0.202 \mu \mathrm{m}$ and $0.650 \pm 0.310 \mu \mathrm{m}$. The mean zeta potentials of insulin and ESCloaded-NPs nanoparticles were found as $6.88 \pm 0.729 \mathrm{mV}, 5.13 \pm 0.631 \mathrm{mV}$. The polydispersity index of insulin and ESC nanoparticles were $0.660 \pm 0.175,0.620 \pm 0.205$ respectively. Encapsulation efficiency of insulin and ESC-loaded-NPs were found to be $50 \pm 1.53 \%$ and $51 \%$. Insulin release from nanoparticles was found to be $72.8 \%$ over $48 \mathrm{~h}$. Glucose concentrations were decreased to 201 and $202.7 \mathrm{mg} / \mathrm{dL}$ from $250 \mathrm{mg} / \mathrm{dL}$ in streptozocin (STZ) induced diabetic mice group after insulin and ESC-loaded-NPs administration. Insulin and ESCloaded-NPs improved the blood insulin levels in all experimental groups. These NPs may be used for repairing of pancreatic cells. Healing or some degree of regeneration was observed when insulin and ESC-loaded-NPs were administered to mice. ESC-loaded-NPs can be a potential source for cell replacement therapy in the treatment of diabetes.
\end{abstract}

Keywords: embryonic stem cell, insulin, PLGA nanoparticles, diabetes, pancreatic beta TC cell

Diabetes is one of the most common diseases that affect people all over the world. When insulin cannot be secreted from the pancreas or if the body cannot effectively use insulin, diabetes occurs. In diabetes, abnormal metabolisms of carbohydrates, fats, and proteins are involved (1-3). Diabetes mellitus is divided into two groups as insulin dependent type I and insulin independent type II. In both types, any defect of beta cell in Langerhans islets causes insulin insufficiency or absence $(2,4)$. Insulin is a major anabolic hormone, which is the most effective molecule for the control of blood glucose levels in diabetes $(1,2)$. Glucose uptake by liver, muscle, and fat tissues can be achieved by the action of insulin
(2). Insulin is the standard treatment for Type 1 and Type 2 diabetic patients. Insulin and other protein or peptide drugs are administered by intramuscular or subcutaneous injections, which unfortunately cause a great discomfort for patients (5-7). Insulin injections are the only available option for diabetic patients to control their blood glucose level. Parenteral administration of insulin has many disadvantages such as common infections, pain caused by subcutaneous injections, stress due to long-term use, and low patient compliance $(1,6,8)$.

The number of diabetic stem cell related studies are increasing in popularity (4). ESCs have been proposed to be a powerful tool to overcome pancre-

\footnotetext{
* Corresponding author: e-mail: zdegim@gmail.com
} 
atic disease, as well as a potential source for cell replacement therapy in the treatment alternatives of diabetes. ESCs can generate many different cell types and they are potential sources of pancreatic beta cells because of their self-renewing properties (9). ESCs are multipotent cells derived from the inner cell mass (ICM) of 3-5 days old embryos (1012).

Many previous studies indicate that polymeric nanocarriers have some advantages for peptide and protein delivery. Polymeric carriers, nanoparticles are solid and spherical structures (13) that have been used in diagnostic kits, therapeutics, and biomedical tools; they can protect encapsulated drugs from severe external conditions and provide a sustained or controlled drug release $(1,14,15)$. These NPs can be prepared with proteins (albumin, gelatin, etc.). NPs can degrade in biological mediums, representing a significant improvement over traditional delivery systems in terms of efficiency and effectiveness $(16,17)$. Preparations of these systems were reported to be simple and rather easy to scale-up, they

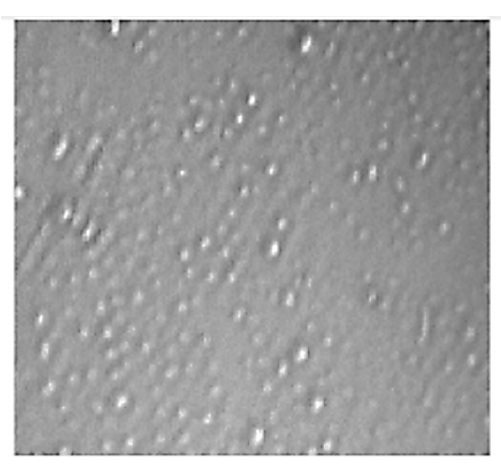

A

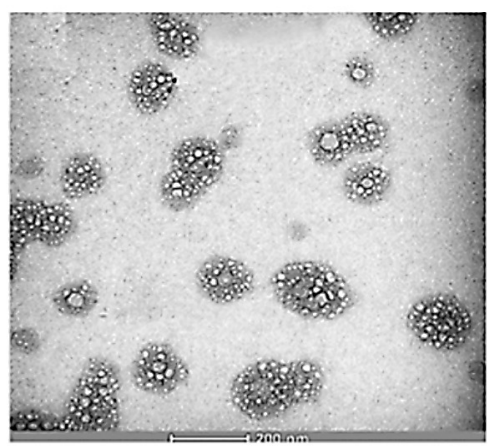

C

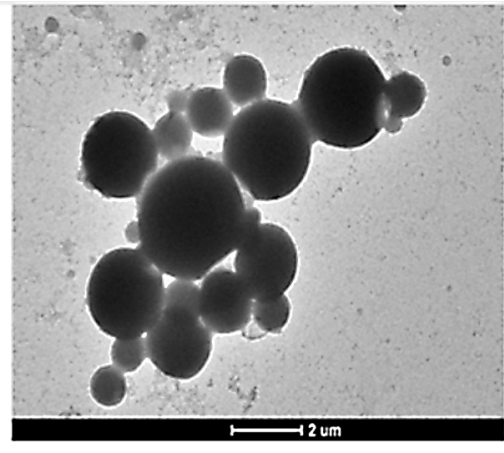

B
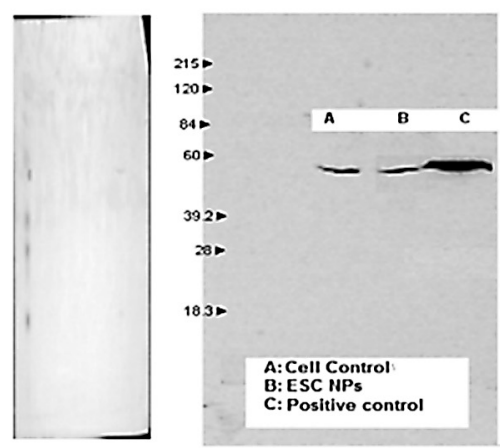

D

Figure 1. (A) Polarize microscope image of nanoparticles $(\times 100)$. (B) TEM of insulin nanoparticles, (C) ESC nanoparticles $(\times 2000)$, (D) Immunoblots of cell control, ESC NP and positive control for encapsulation efficiency

Table 1. Design of experimental animal groups $(\mathrm{n}=3)$.

\begin{tabular}{|c|c|c|}
\hline Group numbers & Group names & Treatment \\
\hline Group 1 & Control & No formulation \\
\hline Group 2 & Insulin solution $(10 \mathrm{IU})$ & Intraperitoneal \\
\hline Group 3 & Insulin nanoparticles $(10 \mathrm{IU})$ & Intraperitoneal \\
\hline Group 4 & ESC (suspand stem cell) $\left(1.2 \times 10^{6} / \mathrm{mL}\right.$ cell) & Intraperitoneal \\
\hline Group 5 & ESC nanoparticles $\left(1.2 \times 10^{6} / \mathrm{mL}\right.$ cell $)$ & Intrapancreatic \\
\hline Group 6 & ESC (suspand stem cell) $\left(1.2 \times 10^{6} / \mathrm{mL}\right.$ cell $)$ & Intrapancreatic \\
\hline Group 7 & ESC nanoparticles $\left(1.2 \times 10^{6} / \mathrm{mL}\right.$ cell $)$ & \\
\hline
\end{tabular}


have improved biodistribution, and their therapeutic efficacy allows sustained drug release at the targeted site over a period of days or even weeks after the administration (18).

Poly lactic-co-glycolic acid (PLGA), is one of the most successfully developed biodegradable polymers that has been extensively used as a drug delivery system for protein and peptides $(6,13,15)$. PLGA is approved by the US Food and Drug Administration (FDA) and European Medicine Agency (EMA) for various drug delivery systems. PLGA based nanoparticles can protect drugs from degradation and enhance their stabilities $(13,15)$.

Western blot analysis is one of the most widely used methods to analyze specific proteins. To determine protein loading, the most commonly used control material is $\beta$-actin. $\beta$-actin is a $43-\mathrm{kDa}$ protein that is found nearly in all eukaryotic cells at various concentrations. One advantage of using $\beta$-actin is that it is very common material and it can be used for many different species $(18,19)$.

The encapsulation efficiencies were determined by western blot analysis. This study compares the effect of insulin and ESC-loaded NPs formulations on pancreatic beta TC cell regeneration. Bovine Serum Albumin (BSA) was used as a reference protein for ESC using the Lowry method. BSA has been widely used in drug delivery systems because of easiness of purification, low cost, and representing no unusual ligand-binding properties (12).

In this study, insulin and ESC-loaded NPs were prepared and their effects on pancreatic beta TC cells were determined. Characterization studies of NPs were performed. The effect of insulin and ESC loaded NPs were investigated by examining blood insulin and glucose levels. Lower blood glucose levels were obtained after ip administration of insulin or ESC loaded NPs. Some degree of healing or pancreatic cell regeneration was also observed with these formulations.

\section{MATERIALS AND METHODS}

\section{Materials \\ Insulin was purchased from Lilly France (Humulin® R $100 \mathrm{IU} / \mathrm{mL}$ ), Bovine Serum Albumin}

(BSA), Poly lactic-co-glycolic acid (PLGA), streptozocin (STZ) and MTT (3-(4,5-dimethyldiazol-2yl)-2,5 diphenyl tetrazolium bromide) were obtained from Sigma, USA. Polyvinyl alcohol (PVA) was provided by Wecker- Germany. Dulbecco's modified Eagle's medium (DMEM) was purchased from Biochrom, Germany. Insulin ELISA kit was from RayBio, Germany. Glucose Liquicolor kit was purchased from Stanbio Lab, USA. Pancreatic Beta TC ( $\beta \mathrm{TC}$ ) and embryonic stem cells were obtained from American Type Culture Collection (ATCC), Manassas, USA.

\section{Methods}

\section{In vitro studies}

NPs preparation

NPs were prepared using emulsification and solvent evaporation technique $(13,15)$. PLGA was used as a polymer. PLGA (400 mg) was dissolved in dichloromethane:methanol $(9: 1)$ at room temperature then injected slowly $(0.5 \mathrm{~mL} / \mathrm{min})$ into aqueous phase containing insulin and $0.4 \%$ PVA. The mixture was stirred at $13500 \mathrm{rpm}$ by Ultraturrax ${ }^{\circledR}$ for 10 min and $100 \mathrm{~mL}$ of distilled water added after evaporation, NPs suspensions were centrifuged at 10000 rpm for $30 \mathrm{~min}$ at $4^{\circ} \mathrm{C}$ and insulin-loaded NPs were obtained.

ESC $1.2 \times 10^{6} / \mathrm{mL}$ cell and suspension of blank NPs incubated for $1 \mathrm{~h}$ for cell labeling. The medium was then changed and cells were incubated for further $48 \mathrm{~h}$ (20). NPs suspensions were centrifuged at $10000 \mathrm{rpm}$ for $30 \mathrm{~min}$ at $4^{\circ} \mathrm{C}$ and ESC loaded NPs were obtained.

\section{Characterization of NPs}

Particle size, polydispersity index (PDI) and zeta potentials of NPs were measured by Malvern Zetasizer Nano ZS (Malvern Instruments, Worcestershire, UK). Physical appearances of the NPs were determined using a microscope (Leica DMEP polarized microscope). Amount of the drug in the supernatant was determined and then encapsulation efficiency (EE) of insulin was calculated (21-23). The protein content was determined by Lowry method, and used for the quantification of insulin. Spectrophotometric determination was carried out at $754 \mathrm{~nm}$.

Table 2. AUC values of insulin-loaded formulations and insulin solution after intraperitonally administration.

\begin{tabular}{|c|c|c|}
\hline Formulations & Solution & Nanoparticle \\
\hline AUC $(\mu \mathrm{g} / \mathrm{mL})$ & $30127^{\mathrm{a}}$ & $21026.25^{\mathrm{b}}$ \\
\hline AUC $(\%)$ & $120630^{\mathrm{a}}$ & $84105^{\mathrm{b}}$ \\
\hline
\end{tabular}

$\mathrm{a}-\mathrm{b}=\mathrm{p}<0.001$ 
The method was found to be linear $\left(r^{2}=0.999\right)$ and reproducible.

$\mathrm{EE}(\%)=\frac{\text { Theoretical amount of insulin-free insulin in supernatant }}{\text { Theoretical amount of insulin }} \times 100$

\section{Insulin release from NPs}

Release studies were performed using Franz diffusion cells with attached 12000 Dalton pore size dialysis membranes. $2.0 \mathrm{~mL}$ insulin NPs suspensions were placed into the donor compartment of the diffusion cells. The receiver compartments were filled with $2.0 \mathrm{~mL}$ of phosphate buffer ( $\mathrm{pH} 7.4$ ). Insulin release studies were performed for $48 \mathrm{~h}$ at $37^{\circ} \mathrm{C}$. $2.0 \mathrm{~mL}$ of samples were withdrawn at predetermined time points and fresh buffer was immediately replenished with the same volume. The samples were then analyzed by Lowry method as described above.

\section{Cytotoxicity assay}

Cytotoxicity of all formulations was examined. Cell viability on pancreatic beta TC cells - after insulin loading, MTT (3-(4,5-dimethyldiazol-2-yl)2,5 diphenyl tetrazolium bromide) tests were carried out. The effects of formulation components on cell viabilities were also investigated for $48-\mathrm{h}$. The color densities were measured at $570 \mathrm{~nm}$ using multi-well ELISA reader.

\section{Transport experiments from cell monolayers}

Beta TC cells were seeded with the concentration of $2.5 \times 10^{5}$ cells $/ \mathrm{cm}^{2}$ on polycarbonate membranes with a pore size of $0.4 \mathrm{~mm}$. The beta TC monolayers containing membranes were placed between the donor and receptor compartments of vertical diffusion cells. $95 \% \mathrm{O}_{2}$ and $5 \% \mathrm{CO}_{2}$ were delivered to the system at $37^{\circ} \mathrm{C}$ to maintain cell viability. Transport experiments were performed from the apical to the basolateral compartment. Samples were collected from the basolateral compartments at $15,30,45,60,90,120,180,240,360,480,720$, 1440, 2160 and 2880 minutes. Monolayer integrities were assessed by transepithelial electrical resistance (TEER) measurements across the cell monolayers. TEER was measured before and after the experiments. Insulin contents of the samples were then analyzed by the Lowry method and Papp values were calculated using following equation (24-26):

$$
P_{\text {app }}=\frac{\mathrm{d} Q}{\mathrm{~d} t} \frac{1}{A C_{0}}
$$

$\mathrm{dQ} / \mathrm{dt}$ refers to the permeability rate, $\mathrm{A}\left(\mathrm{cm}^{2}\right)$ is the area of the membrane (diffusional area), and $\mathrm{C}_{0}$ $(\mathrm{mg} / \mathrm{mL})$ refers to the initial concentration of doxycycline in donor compartment.

\section{Incubation of living cells with NPs}

Beta TC cells $\left(2.5 \times 10^{5}\right.$ cells $\left./ \mathrm{mL}\right)$ were seeded to the wells and three different groups were studied. No treatment was applied to the first group. Initial amount of insulin and glucose levels were determined. Glucose and insulin concentrations in the samples were measured using Glucose Liquicolor and Mouse Insulin ELISA kit.

In the second group, beta TC cells incubated with Krebs-Ringer bicarbonate buffer (KRB) (119 $\mathrm{mM} \mathrm{NaCl}, 4.7 \mathrm{mM} \mathrm{KCl}, 2.54 \mathrm{mM} \mathrm{CaCl}_{2}, 1.19 \mathrm{mM}$ $\mathrm{MgSO}_{4}, 1.19 \mathrm{mM} \mathrm{KH} \mathrm{KO}_{2}, 25 \mathrm{mM} \mathrm{NaHCO}$ ) for $1 \mathrm{~h}$. The KRB was removed and all cells were incubated with KRB containing glucose $(25 \mathrm{mM})$ for $2 \mathrm{~h}$ (27). Prepared cells were incubated with insulin and ESC-loaded NPs for $48 \mathrm{~h}$. After the incubation, treated cells were centrifuged at $800 \mathrm{rpm}$, for $5 \mathrm{~min}$ and insulin and glucose levels were measured from the supernatants.

In the third group, beta TC cells incubated with STZ. Glucose level equal or over than $250 \mathrm{mg} / \mathrm{dL}$ were considered diabetic in the study (28). Insulin and ESC-loaded NPs incubated with this group for 48 h. After the incubation, treated cells were centrifuged at $800 \mathrm{rpm}$, for $5 \mathrm{~min}$ and insulin and glucose levels were measured from supernatants as described above.

After the experiments, immunoblot analyses were performed. Protein levels were measured using a Bio-Rad assay kit. Membranes were probed with antibodies against to $\beta$-actin. The immunoreactive proteins were detected by chemiluminescence (West Pico chemiluminescent substrate/Thermo-Pierce). Nitrocellulose membranes were stripped out and re-probed with antibodies against the $\beta$-actin. Protein bands were digitally imaged for densitometric quantitations.

\section{In vivo studies}

Balb-C type, 12-13 weeks old male mice were used. Animal studies were conducted under the protocol approved by the Animal Care and Use Ethical Committee of Gazi University (G.U.N.ET-12.075).

To induce experimental diabetes, STZ solutions in sodium citrate buffer ( $\mathrm{pH}$ : 4.5) were injected ip (150 mg/kg) (29) to the animals. Blood glucose levels were measured by glucose kit 2 days after STZ injections. Glucose levels $>250 \mathrm{mg} / \mathrm{dL}$ were accepted to be diabetic (30).

The animals were divided into 7 groups, 3 animals were used in each group. Formulations were administrated to the animals ip, ESC suspensions and ESC loaded NPs were administrated to the animals both intrapancreatic and ip. The design of the animal groups was shown in Table 1 . 
Blood samples were collected at predetermined time points $(0.25,0.5,1,2,4,6,8,24 \mathrm{~h})$. The plasma glucose and insulin concentrations were measured using a glucose kit and mouse insulin ELISA kit respectively and the areas under curves (AUC) were calculated.

\section{Histopathological studies}

After the treatment, pancreases of mice were taken out and kept in formaldehyde solutions (10\%). Tissue sections $(110 \mu \mathrm{m})$ were stained with Hematoxylin \& Eosin dye and evaluated under a light microscope (Olympus BX51). The severity and prevalence of degenerations of the pancreas, surface areas were classified semiquantitatively (0: normal; 1: minimal; 2: slight; 3: middle; 4: distinctive; 5: severe). Also, semidiameters and covered areas of Langerhans islets were measured.

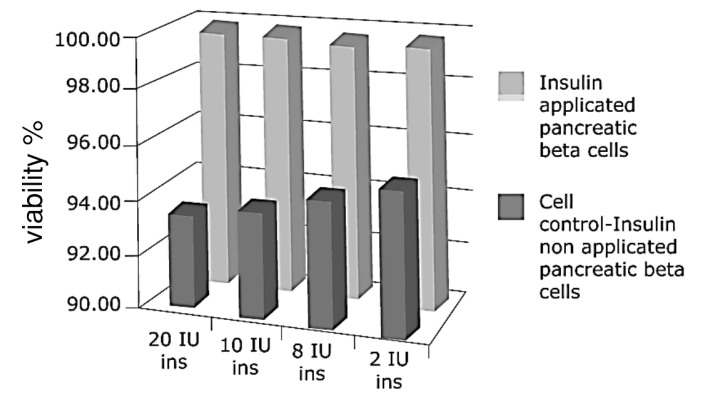

A

Figure 2. Insulin with different concentration on $\beta$ TC cell viability (A) Free nanoparticle effects on $\beta$ TC cell viability (B)

\section{Statistical analysis}

All data in this study were considered as means $\pm \mathrm{SD}$, and one-way ANOVA tests were used for statistical analyses. GraphPad InStat computer program was used.

\section{RESULTS AND DISCUSSION}

In this present study, it was observed that insulin and ESC-loaded NPs are effective on pancreatic beta cells and insulin and ESC-loaded formulations found to induce pancreatic beta TC regeneration.

\section{Characterization Studies}

The physical appearance of nanoparticles was determined using a polarized light microscope and TEM (Fig. 1). Mean particle sizes of insulin and

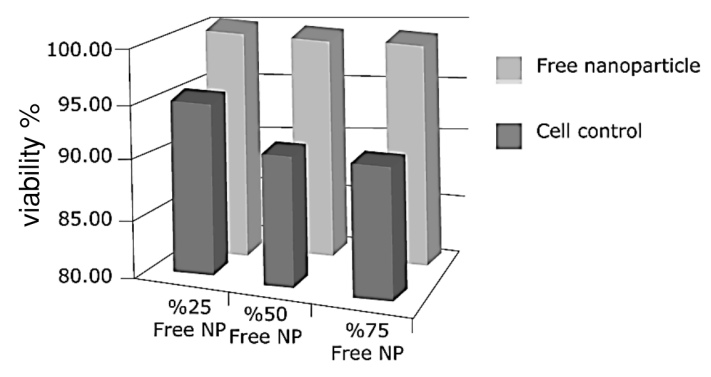

B

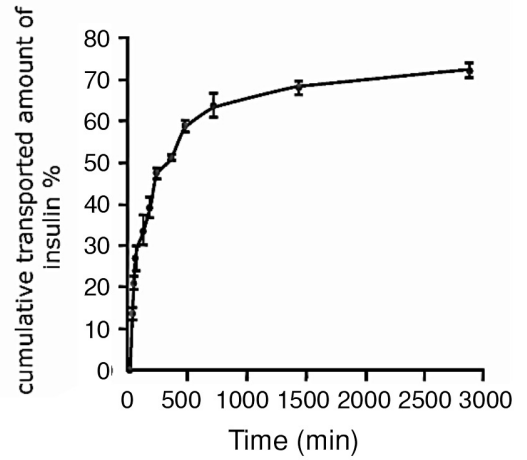

A

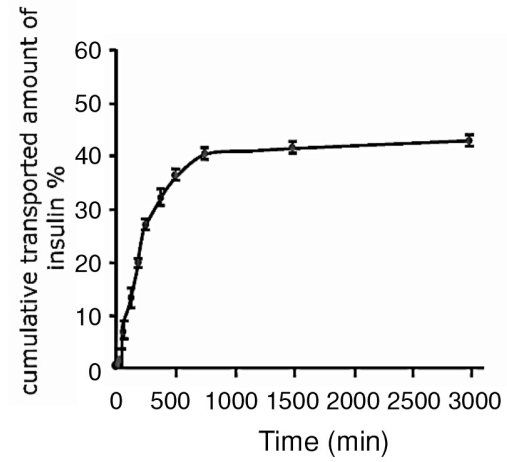

$\mathrm{B}$

Figure 3. (A) In vitro release profiles of insulin from nanoparticles at $\mathrm{pH} 7.4$ phosphate buffer from dialysis membrane, (B) Cumulative amount of insulin from nanoparticles transported through $\beta$ TC cell monolayers (error bars represent standard deviations, $\mathrm{n}=3$ ) 
ESC NPs were determined to be $0.665 \pm 0.202 \mu \mathrm{m}$ and $0.650 \pm 0.310 \mu \mathrm{m}$. The mean zeta potentials of insulin and ESC NPs were $6.88 \pm 0.729 \mathrm{mV}, 5.13 \pm$ $0.631 \mathrm{mV}$. The polydispersity indexes of insulin and ESC NPs were found to be $0.660 \pm 0.175,0.620 \pm$ 0.205 respectively. Encapsulation efficiency of insulin NPs was found to be $50 \pm 1.53 \%$. For ESC NPs encapsulation efficiencies were measured with three different methods (Lowry method $51 \%$, cell counting $50.4 \%$ and western blot analysis 51.2\%). Encapsulation efficiencies were also obtained from the literature. Insulin-loaded chitosan nanoparticles were prepared and encapsulation efficiency of these nanoparticles was reported to be $52.76 \%$ (6). Another study was carried out to evaluate the encapsulation efficiency of BSA-loaded PLGA microspheres. Total protein assay was performed using the Lowry method and the total protein loading and surface-associated proteins were found to be $8.61 \%$ and $16.6 \%$, respectively (31). Our encapsulation efficiency of insulin NPs appeared to be comparable and good enough.

Western blot analysis of the densitometric quantitation of the $\beta$-actin signals is shown in Figure
1D. Control was accepted as $100 \%$. Western blot percentages found by cell counting and Lowry; both determinations were found to be compatible with each other.

\section{Citotoxicity}

The effect of insulin-loaded and unloaded NP formulations on beta TC cell viabilities were investigated for $48 \mathrm{~h}$ using the MTT method. The effect of Dulbecco's modified Eagle medium (DMEM) was also tested. The viability of cells as percentages is given in Figure 2A and B. According to MTT test results, the insulin concentration was selected with the value of $10 \mathrm{IU}$.

MTT tests were carried out to determine the toxic levels of insulin and NPs containing PLGA and PVA. Insulin was not found to cause any cellular toxicity with used dose (10 IU). Our dose was $10 \mathrm{IU} / 30 \mathrm{~g}$ (67 IU/kg) for IP administration. The dose in the literature was found to be varied for IP administrations for rats (33 - $80 \mathrm{IU} / \mathrm{kg})$ (32), 667 IU/kg dose was used for intraduodenal administration for rats in the literature (33) but, the ip dose used in this study was found to be applicable.

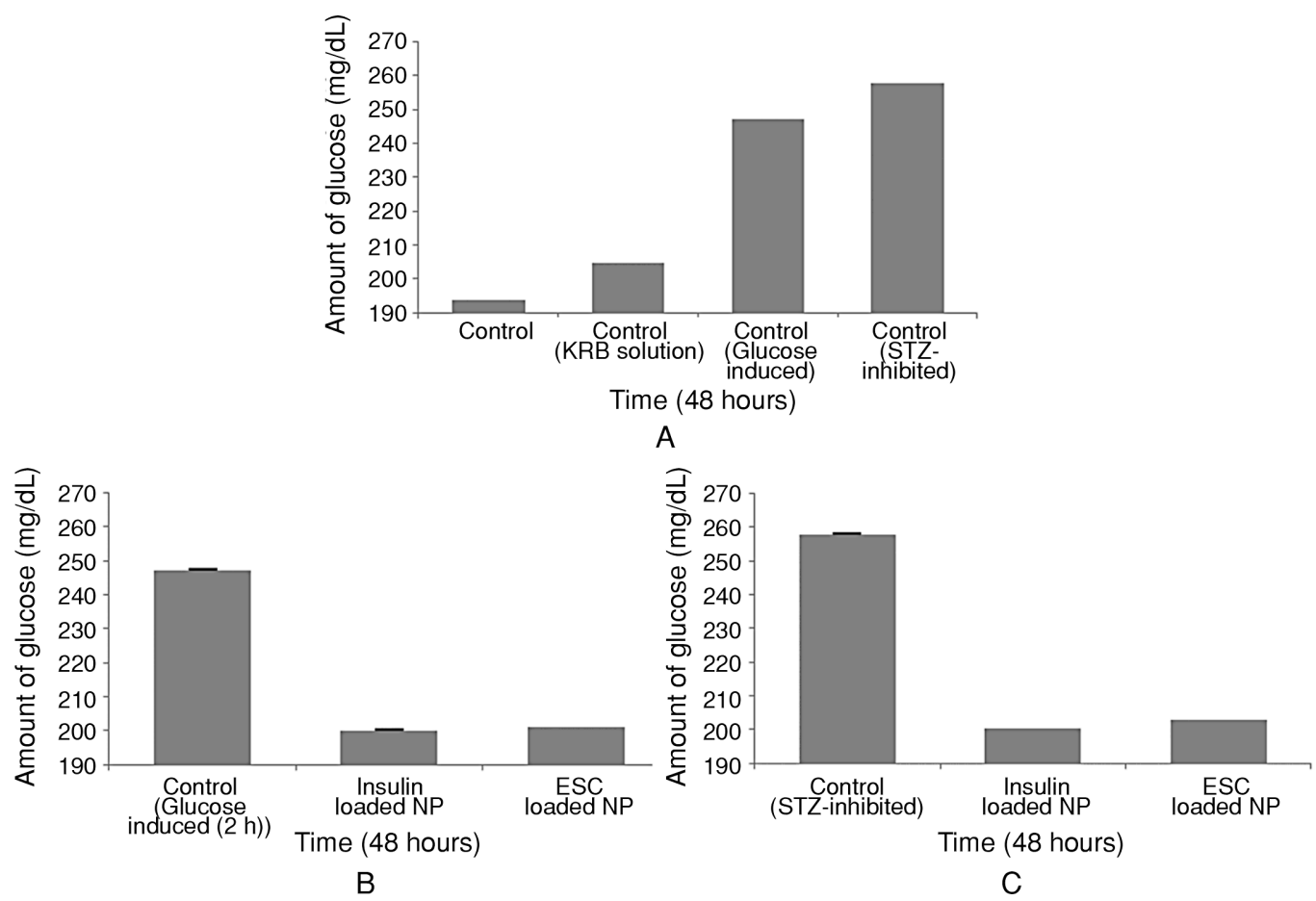

Figure 4. (A) Control groups, Glucose \% after incubation with KRB buffer, glucose and streptozocin solution using pancreatic $\beta$ TC cells, (B) Glucose levels after incubation with insulin and ESC loaded NPs using glucose-induced pancreatic $\beta$ TC cells and (C) Glucose levels after incubation with insulin and ESC loaded NPs using STZ-inhibited pancreatic $\beta$ TC cells (error bars represent standard deviations, $\mathrm{n}=3$ ) 

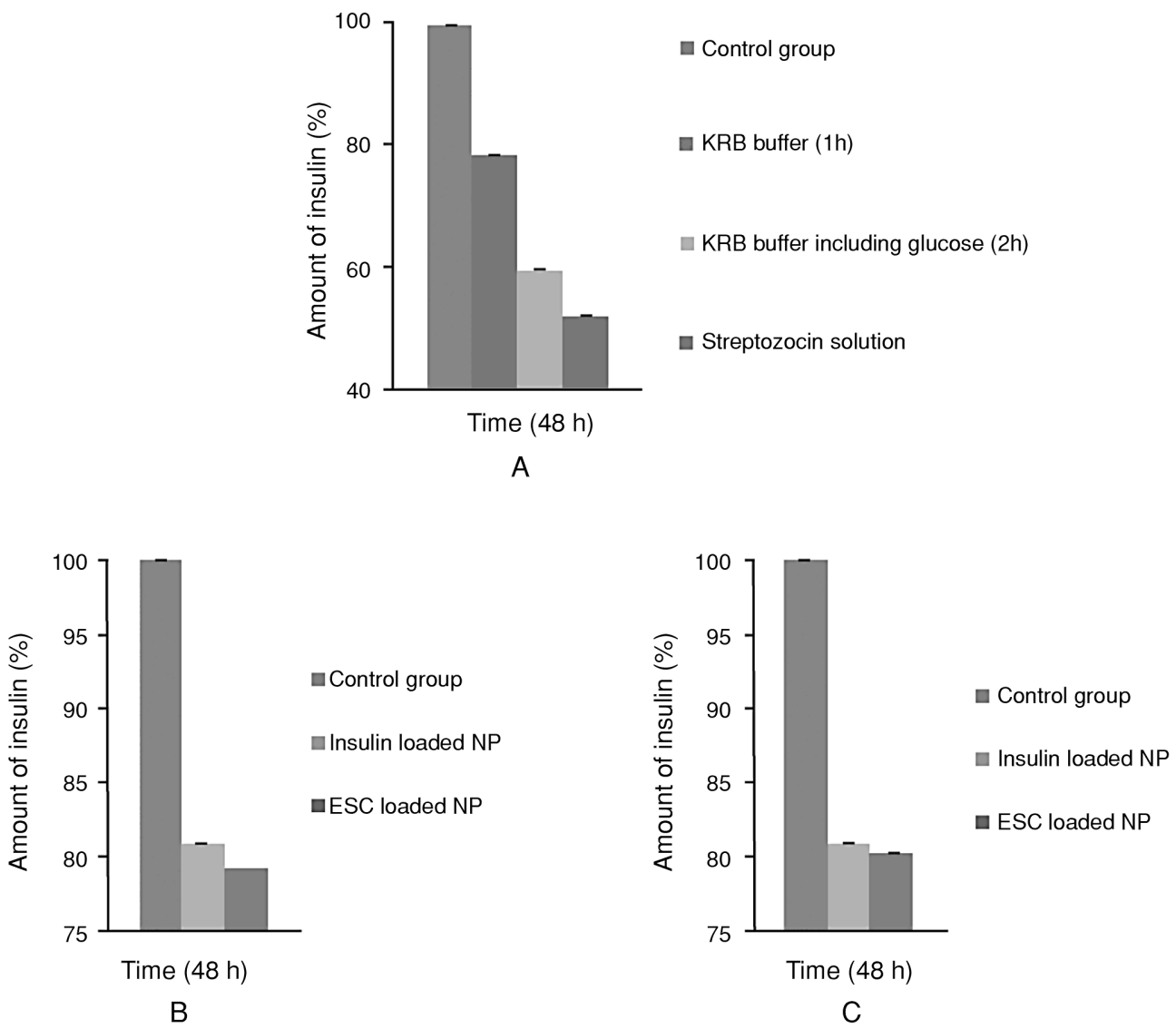

Figure 5. (A) insulin \% after incubation with glucose and streptozocin solution against to control group using pancreatic $\beta$ TC cells, (B) insulin levels \% after incubation with insulin and ESC loaded NPs using glucose-induced pancreatic $\beta$ TC cells and (C) STZ-inhibited pancreatic $\beta$ TC cells (error bars represent standard deviations, $\mathrm{n}=3$ )

Additionally, empty nanoparticles were also not found to be toxic to cells at any concentrations. In other studies in the literature, MTT assay was performed using Caco-2 cell with blank PLGA-NP. It was reported that cell viability did not alter after $3 \mathrm{~h}$ of the incubation with blank PLGA-NP at 1-25.5 $\mathrm{mg} / \mathrm{mL}$ concentrations (6).

\section{In vitro releases and transport studies of insulin from NPs}

In vitro insulin release experiment from NPs formulation was performed using Franz-type diffusion cells. Insulin release from NPs was found to be $72.8 \%$. Release profiles of insulin from NPs are given in Figure 3A.

Transport experiments of insulin from NPs from the apical side to the basolateral compartments were evaluated. Results are given in Figure 3B. Cumulative amounts of insulin at the end of the 48hour time period were calculated. $\mathrm{P}_{\text {app }}$ values were calculated for NP formulation as $1.06 \mathrm{~cm} / \mathrm{h}$. The values of TEER were measured before and after the experiment for NPs. TEER values were found to be 79 and 72 ohms for the control group and insulin NPs, respectively.

In vitro insulin release experiment from NP formulation was performed through dialysis membrane using Franz-type diffusion cells at $\mathrm{pH} 7.4$ and $37^{\circ} \mathrm{C}$. Insulin release from NPs was found to be $72.8 \%$. In the literature, insulin solid lipid nanoparticles formulation (Witepsol E85/PVA at 1\%) was prepared and in vitro release studies were performed at $\mathrm{pH}$ 7.4. Insulin was reported to be released from the formulation $39 \%$ after $48 \mathrm{~h}$ (34).

\section{Incubation of cells with NPs}

Glucose level determinations of cells after incubated with NPs following exposure of KRB buffer having glucose and STZ are given in Figure 4A. Insulin and ESC loaded NPs were administered 
to beta TC cells and glucose level analyses were performed. Induction or inhibition of glucose levels against to control groups were given (glucoseinduced groups (Fig. 4B), STZ-inhibited groups (Fig. 4C)).

Concentrations of glucose and insulin in diabetic cells were determined using assay kits after $48 \mathrm{~h}$. Glucose concentrations were found significantly increased from $193.5 \mathrm{mg} / \mathrm{dL}$ to $247.1 \mathrm{mg} / \mathrm{dL}$ and $257.7 \mathrm{mg} / \mathrm{dL}(\mathrm{p}<0.0002)$ for glucose-induced and STZ-inhibited cells respectively. Glucose concentrations were found significantly reduced back after incubated with insulin and ESC loaded NPs for both glucose-induced and STZ inhibited cells (glucoseinduced cells and insulin-loaded NPs applied group: $199.9 \mathrm{mg} / \mathrm{dL}$; glucose-induced cells, and ESC loaded NPs applied group: $201 \mathrm{mg} / \mathrm{dL}, \mathrm{STZ}$-inhibited cells, and insulin-loaded NPs applied group: 200 $\mathrm{mg} / \mathrm{dL}$, STZ-inhibited cells, and ESC loaded NPs applied group: $202.7 \mathrm{mg} / \mathrm{dL}(\mathrm{p}<0.001)$ ).

After the treatment, decreased glucose levels were found to be comparable with the control group. Glucose levels were found to be $103.31 \%$ and $103.88 \%$ for insulin and ESC loaded NPs for $48 \mathrm{~h}$, respectively (control group: $193.5 \mathrm{mg} / \mathrm{dL}(100 \%)$ ) in the glucose-induced group. Similarly, in STZ-inhibited group, glucose levels were also decreased and they were found to be $103.36 \%$ and $104.75 \%$ for insulin and ESC loaded NPs respectively.

Insulin levels, after exposure to KRB buffer having glucose or STZ, are given in Figure 5A, insulin and ESC-loaded NPs on beta TC cells were performed after induction or inhibition of glucose (Fig 5B) of STZ groups against control group are given Fig 5C. In glucose and STZ-induced cells insulin concentration was measured as $59.8 \%$ and $52.1 \%$. After the treatment with insulin and ESC loaded NPs for $48 \mathrm{~h}$, these levels increased to $81.4 \%$ and $79.3 \%$ in a glucose-induced group. In STZinduced group, these levels increased to $80.9 \%$ and $80.3 \%$ respectively.

\section{In vivo studies}

Insulin solution and NPs were applied to animals ip or through intrapancreatic route (Fig. 6). The plasma glucose \% (Fig. 7a) and insulin concentrations (Fig. 7b) were measured using a glucose assay kit and mouse insulin ELISA kit respectively. After IP administration, the areas under curves (AUC) were calculated and given in Table 2 .

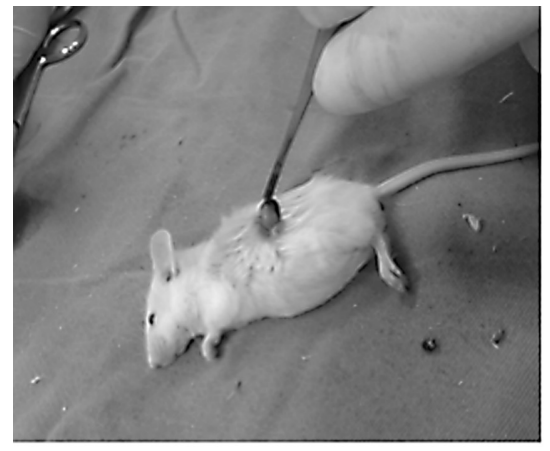

A

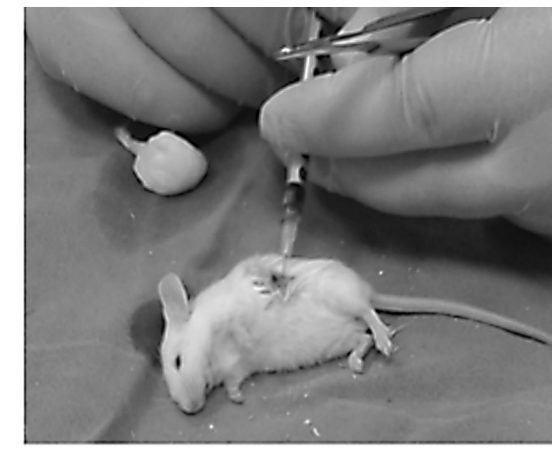

B

Figure 6. (A) Mouse pancreas, (B) intrapancreatic administration

Table 3. The total semidiameter, footprint and degenerations of a cross-sections taken in Langerhans islets (48 h).

\begin{tabular}{|l|c|c|c|}
\hline \multicolumn{1}{|c|}{ Groups } & $\begin{array}{c}\text { The total semidiameter of } \\
\text { a cross section taken in the } \\
\text { islets of Langerhans }(\mu \mathrm{m})\end{array}$ & $\begin{array}{c}\text { The footprint of a cross } \\
\text { section taken in the islets } \\
\text { of Langerhans }\left(\mathrm{mm}^{2}\right)\end{array}$ & $\begin{array}{c}\text { Degeneration of } \\
\text { Langerhans islets* }\end{array}$ \\
\hline Control & 430 & 0.54 & 0 \\
\hline Solution & 289 & 0.36 & 0.10 \\
\hline Insulin nanoparticle & 238 & 0.18 & 0 \\
\hline
\end{tabular}

*0: normal; 1: minimal; 2: slight; 3: middle; 4: distinctive; 5: severe 


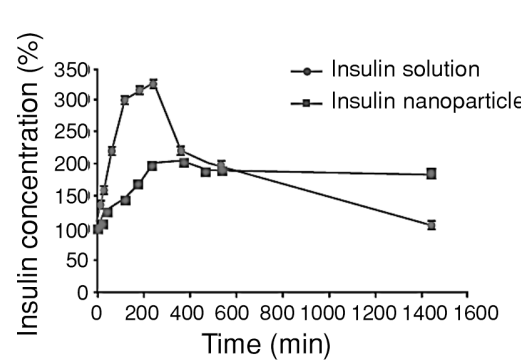

A

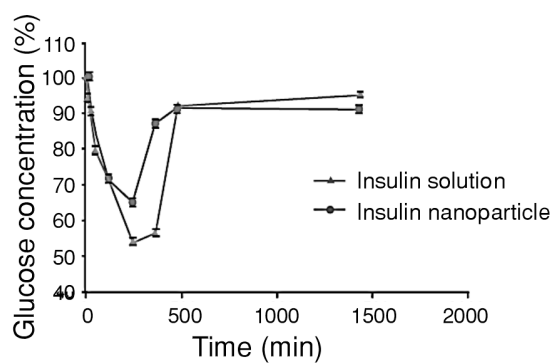

$\mathrm{B}$

Figure 7. (A) insulin concentration \% (B) glucose concentration $\%$ and time profile for insulin solution and nanoparticle (error bars represent standard deviations, $\mathrm{n}=3$ )

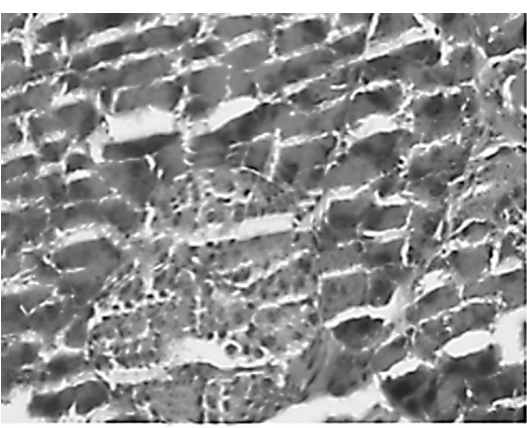

A

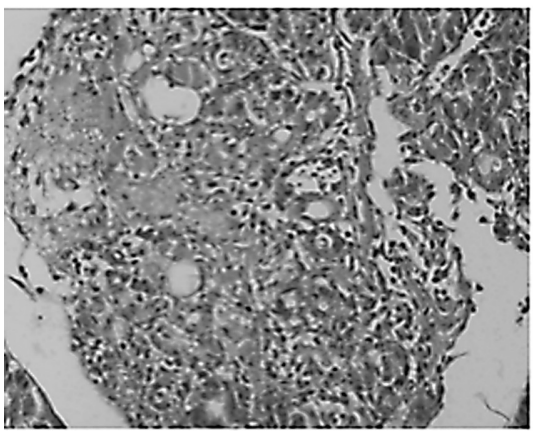

C

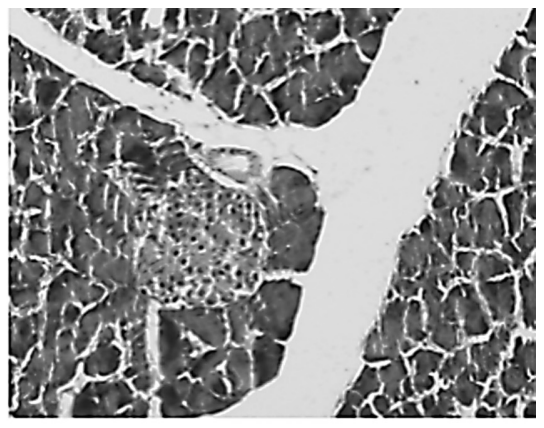

B

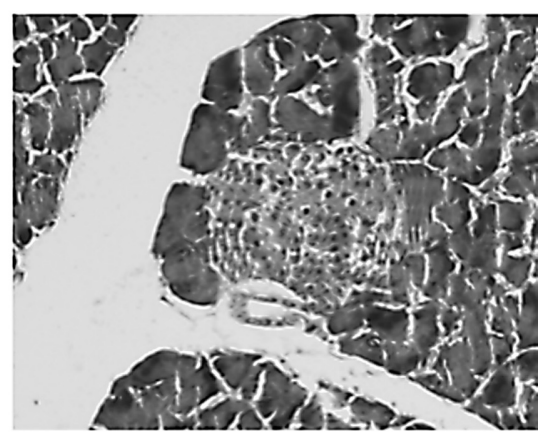

D

Figure 8. Pathological examination results of pancreatic sections of control group (A), ip administration of insulin-loaded NP (B), intrapancreatic administration from ESC-NP (C), ip administration of NP (D) (Light microscope $\times 20)$

Table 4. Glucose concentrations after ESC NP administrations to diabetic mice (after 48 and $120 \mathrm{~h}$ ).

\begin{tabular}{|c|c|c|c|}
\hline Groups & $\begin{array}{c}\text { Glucose concentration }(\mathrm{mg} / \mathrm{dL}) \\
(\mathrm{ip}) \\
(48 \mathrm{~h})\end{array}$ & $\begin{array}{c}\text { Glucose concentration }(\mathrm{mg} / \mathrm{dL}) \\
\text { (intrapancreas) } \\
(48 \mathrm{~h})\end{array}$ & $\begin{array}{c}\text { Glucose concentration }(\mathrm{mg} / \mathrm{dL}) \\
(\mathrm{ip}) \\
(120 \mathrm{~h})\end{array}$ \\
\hline Control & $104.5 \pm 0.325^{*}$ & $105.3 \pm 1.25^{\mathrm{a}}$ & $104.5 \pm 0.320^{\mathrm{c}}$ \\
\hline ESC Nanoparticle & $106.4 \pm 0.437^{*}$ & $109.8 \pm 1.30^{\mathrm{b}}$ & $103.2 \pm 1.47^{\mathrm{d}}$ \\
\hline ESC (suspended) & $105.1 \pm 0.528^{*}$ & ---- & $110.9 \pm 3.01^{\mathrm{e}}$ \\
\hline
\end{tabular}

Values are expressed as mean \pm standard deviation $(n=6),{ }^{*}$ Not significant from control group $p>0.05, a-b=p<0.002, b-c=p>0.005$, $\mathrm{d}-\mathrm{e}=\mathrm{p}<0.05$ 


\section{Histopathological studies}

After IP administration of insulin solutions and insulin-loaded NPs to diabetic mice, the severity and prevalence of degenerations of pancreas cells, surface areas, semidiameters, and covered areas of Langerhans islets are given in Table 3.

In the islet of Langerhans cells, tissues were found quite limited, vacuolar degenerations and degenerative changes were observed. A significant difference was not observed between the groups.

After both ip and intrapancreatic administration of ESC NPs and suspended cells to diabetic mice, blood samples were taken after $48 \mathrm{~h}$ and glucose concentration measurements are given in (Table 4).

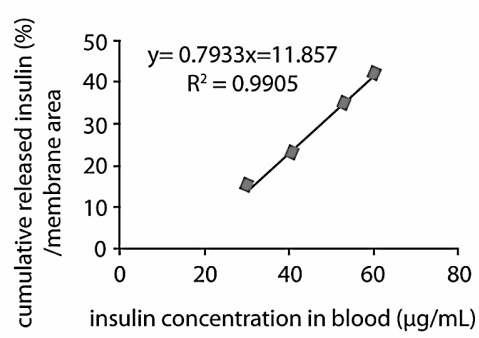

A

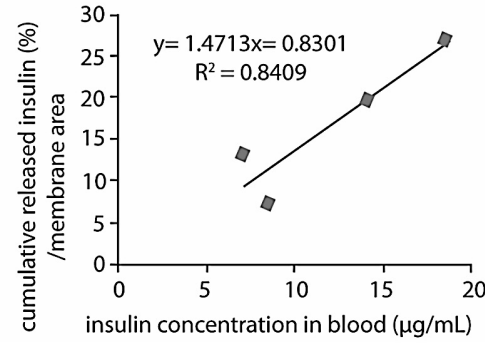

B

Figure 9. In vitro-in vivo correlation results between cumulative amount of insulin (\%) passed through pancreatic beta TC cells and insulin concentration in blood $(\mu \mathrm{g} / \mathrm{mL})$ for insulin solution (A) and nanoparticle (B)

Table 5. The total semidiameter, footprint of a cross-section taken in Langerhans islets and degeneration after intraperitoneal ESC formulation administration. (48 $\mathrm{h}$ and $120 \mathrm{~h}$ ).

\begin{tabular}{|c|c|c|c|c|c|c|}
\hline \multirow[t]{2}{*}{ Groups } & Control & $\begin{array}{c}\text { ESC } \\
\text { (suspended) }\end{array}$ & $\begin{array}{c}\text { ESC } \\
\text { Nanoparticle }\end{array}$ & Control & $\begin{array}{c}\text { ESC } \\
\text { (suspended) }\end{array}$ & $\begin{array}{c}\text { ESC } \\
\text { Nanoparticle }\end{array}$ \\
\hline & \multicolumn{3}{|c|}{$48 \mathrm{~h}$} & \multicolumn{3}{|c|}{$120 \mathrm{~h}$} \\
\hline $\begin{array}{l}\text { The total } \\
\text { semidiameter of } \\
\text { a cross-section taken } \\
\text { in the islets of } \\
\text { Langerhans }(\mu \mathrm{m})\end{array}$ & 654 & 214 & 335 & 756 & 692 & 1092 \\
\hline $\begin{array}{l}\text { The footprint of } \\
\text { a cross-section taken } \\
\text { in the islets of } \\
\text { Langerhans }\left(\mathrm{mm}^{2}\right)\end{array}$ & 1.34 & 0.438 & 0.686 & 0.450 & 0.530 & 2.24 \\
\hline $\begin{array}{c}\text { Degeneration of } \\
\text { Langerhans islets* }\end{array}$ & 0 & 0 & 1.0 & 0 & 0 & 0.1 \\
\hline
\end{tabular}

*0: normal; 1: minimal; 2: slight; 3 : middle; 4: distinctive; 5: severe

Table 6. The Number of a cross-section taken in the islets of Langerhans and degeneration after ESCs and nanoparticle given intrapancreatic. $(48 \mathrm{~h})$.

\begin{tabular}{|c|c|c|c|}
\hline Groups & Control & ESC (suspended) & ESC Nanoparticle \\
\hline Number of a cross section taken in the islets of Langerhans & 5.6 & 5.0 & 2.7 \\
\hline Degeneration of Langerhans islets* & 0 & 1.5 & 1.6 \\
\hline
\end{tabular}

*0: normal; 1: minimal; 2: slight; 3: middle; 4: distinctive; 5 : severe 
After administration of ESC loaded NPs to diabetic mice, the severity and prevalence of degeneration of pancreas surface areas and semidiameters and covered area of Langerhans islets after formulations are given in Table 5 and 6.

The intrapancreatic administration led to severe and widespread degenerations and immune response and infected cells were observed in all formulations especially with NPs. Due to the route of administration, the trauma, inflammatory necrotic reactions, and degenerations have been observed (Fig. 8C).

\section{In vitro-in vivo correlation}

In vitro-in vivo correlation studies were also performed considering the cumulative amount of insulin (\%) passed through apical to the basolateral side of the pancreatic beta TC cell monolayers and blood insulin concentrations values from animal studies. The correlations were shown in Figure 9A and $9 \mathrm{~B}$.

Considering both positive charges and their physical appearances of NPs under TEM, it is the first study in the literature which shows that NPs can actively bind to the surface of ESCs and it is even more interesting that after the ip administration these NPs can move together with ESCs finalizing the trip at the damaged area in the pancreas which is proved by TEM. NPs found to be present on the cell surface and this may provide a sustained action and more opportunity for internalization or penetration (Fig. 1). On the other hand, the possible relationship between glucose and insulin concentrations in diabetic cells induced with glucose and STZ was also investigated. The reduction of insulin concentration was synchronous with the increased glucose level. In the beginning, the level of insulin of the control group was found to be $50 \mu \mathrm{g} / \mathrm{mL}$ (100\%) using mouse insulin ELISA kit. Glucose and STZ-induced cells insulin concentrations were also measured and this difference was found to be significant $(\mathrm{p}<$ 0.0001). After the treatment with insulin and ESC loaded NPs for $48 \mathrm{~h}$, these levels of insulin increased to $180 \%$ in both glucose and STZ-induced groups (Fig. 5).

In the literature, alginate-poly(L)lysine-alginate (APA)-BTC6 and APA-MIN6 cells were encapsulated and evaluated considering their insulin secretions and glucose responses of pancreatic beta cell lines. It was reported that glucose concentrations $(400 \mathrm{mg} / \mathrm{dL}$ ) of hyperglycemic cells decreased to normal levels $(100 \mathrm{mg} / \mathrm{dL})$ by the secretion of a high concentration of insulin after the treatment with APA-MIN6 cells (27).
Western blot analyses were performed to determine ESC encapsulation efficiency using $\beta$-actin. It is becoming a standard practice to measure a housekeeping gene, typically actin, in Western blots (35). Density of the bands measured against to control group and ESC cell activity as a percentage of the installation has been determined. Some studies reported that beta-actin determined by Western blot analysis at various concentrations of beta-actin bands show the protein density. It has been found that increased protein concentrations gave increased density of the bands $(35,36)$.

Diabetes is a serious and prevalent metabolic disease in the world. Scientists are interested in several new approaches such as the using of stem cells to treat diabetes efficiently (37). Ngoc et al used derived mesenchymal stem cells (MSCs) from mouse bone marrow and differentiated them into insulin-producing cells. These cells were encapsulated in an alginate membrane and grafted into diabetic mouse with streptozocin $(50 \mathrm{mg} / \mathrm{kg})$ by ip injections. The treated mice were found to achieve normal blood glucose levels (38).

ESC has two very important features. One of them is renewing itself to proliferate without differentiation, and the other is the potential to create specialized cell types when induced for differentiation. Therefore it was thought that when ESC reached the damaged areas in pancreas in diabetic mice with the help of NPs, the cells possibly transformed into the pancreatic beta cells to overcome the tissue damage there.

ESC NPs were found to be able to repair the damage in the pancreatic cells; even at the $5^{\text {th }}$ day, they exhibited the same glucose levels with the control group. The reason was attributed to less degeneration potential of ESC loaded NPs than ip administrations (Table 6). Intrapancreatic injections caused a strong immune response in pancreatic acinar cells, consequently, it was interpreted that the main problem was widespread degeneration.

The blood glucose levels of ECS loaded NPs applied group were found to be similar to the control group after 5 days because pancreatic beta TC cells were seem to renewed by stem cells.

Figure 8 shows the pancreatic tissue cells under microscope. Healing or regenerations were observed less than the control group for all formulations and the degeneration of the cells in the pancreatic tissues was found to be higher than the control group and ip administration group. Intrapancreatic administration and the immunologic response to stem cells can cause a degeneration of acinar pancreatic cells. The main reason for obtaining undesirable necrotic degeneration was found to be due to 
direct invasive injections to the pancreas. It was thought that although formulations have been applied in nonirritant sterile saline solutions, it might cause some traumatic necroses.

Insulin administration and sustained release can extend the dosing interval times but the treatment with stem cells can actively repair the damaged pancreatic cells and this effect can be long-lasting.

This cell therapy with ESC loaded NPs is considered to be an attractive approach and it can be an alternative to conventional insulin therapy for the treatment of diabetes.

\section{CONCLUSION}

It was concluded that insulin and ESC loaded NPs improved insulin levels when glucose and STZ induced diabetic animals were used. These ESC loaded NPs may be used to repair pancreatic cell degenerations and this ESC treatment will be a potential source for cell replacement therapy for the treatment of diabetes.

\section{Conflict of interest}

The authors state that there are no conflicts of interest pertaining to this manuscript.

\section{Acknowledgments}

This work was carried out at the Faculty of Pharmacy of Gazi University as a PhD thesis and supported by the Scientific and Technological Research Council of Turkey (TÜBÝTAK, No. 112S405).

\section{REFERENCES}

1. He P., Liu H., Tang Z., Deng M., Yang Y. et al.: Int. J. Pharm. 455, 259 (2013).

2. Rekha M.R., Sharma C.P.: Int. J. Pharm. 440, 48 (2013).

3. Han H.W., Yan XL, Dong RX, Ban G., Li K.: Appl. Phys. B 94, 667 (2009).

4. Cilaker Micılı S., Özoğul C.: Dokuz Eylül Universitesi Tıp Fakültesi Dergisi 21, 109 (2007).

5. Zhang N., Li J., Jiang W., Ren C., Li J. et al.: Int. J. Pharm. 393, 212 (2010).

6. Zhang X., Sun M., Zheng Cao D., Bi Y., Sun J.: Eur. J. Pharm. Sci. 45, 632-638 (2012).

7. Reix N., Parat A., Seyfritz E., Van der Werf R., Epure V. et al.: Int. J. Pharm. 437, 213 (2012).
8. Sintov A.C., Levy H.V., Botner S.: J. Cont. Rel. 148, 168 (2010).

9. Fujikawa T., Oh S., Pi L., Hatch H.M., Shupe T., Petersen BE.: Am. J. Pathol. 166, 1781 (2005).

10. Luft S., Pignalosa D., Nasonova E., Arrizabalaga O., Helm A. et al.: Mutat. Res. 760, 56 (2014).

11. Björklund L.M., Sánchez-Pernaute R., Chung S., Andersson T., Chen IYC. et al.: Edited by Gerald D F.: PNAS, 99, 2344-2349 (2002).

12. Hao H., Qingming M., Chong H., He F., Yao P.: Int. J. Pharm. 444, 77 (2013).

13. Danhier F., Ansorena E., Silva JM., Coco R., Le Breton A., Preat V.: J. Cont. Rel. 161, 505 (2012).

14. Surendiran A., Sandhiya S., Pradhan SC., Adithan C.: Indian J. Med. Res. 130, 689 (2009).

15. Faraji A.H., Wipf P.: Bioorg. Med Chem 17, 2950 (2009).

16. Subramani K., Pathak S., Hosseinkhani H.: Dig. J. Nanomater. Bios. 7, 85 (2012).

17. Yedomon B., Fessi H., Charcosset C.: Eur. J. Pharm. Biopharm. 85, 398 (2013).

18. Yücel Ç., Değim Z., Yılmaz Ş.: Biomed. Pharmacother. 67, 459 (2013).

19. Gilda JE., Gomes AV.: Anal. Biochem. 440, 186 (2013).

20. Jo J., Aoki I., Tabata Y.: J. Cont. Rel. 142, 465 (2010).

21. El-Gazayerly O.N., Hikal A.H.: Int. J. Pharm. 158, 121 (1997).

22. Li H., Song J.H., Park J.S., Han K.: Int. J. Pharm. 258, 11 (2003).

23. Cong W., Liu Q., Chen X., Gao R., Lu J. et al.: Drug Dev. Ind. Pharm. 36, 1186 (2010).

24. Raiman J., Törmalehto S., Yritys K., Junginger H.E., Mönkkönen J.: Int. J. Pharm. 261, 129 (2003).

25. Zerrouk N., Corti G., Ancillotti S., Maestrelli F., Cirri M., Mura P.: Eur. J. Pharm. Biopharm. 62, 241 (2006).

26. Meaney C.M., O’Driscoll C.M.: Int. J. Pharm. 207, 21 (2000).

27. Suzuki R., Okada N., Miyamoto H., Yoshioka T., Sakamoto K. et al.: Life Sci. 71, 1717 (2002).

28. Bildirici K., İncedal HE., Özden H., Akyüz F., Cengiz BP., Altuner Y.: Turkish J. Ecopathology 11, 1 (2005).

29. Dekel Y., Glucksam Y., Margalit R.: J. Cont. Rel. 143, 128 (2010).

30. Baydas G., Canatan H., Türkoğlu A.: J. Pineal. Res. 32, 225 (2002). 
31. Igartua M., Herna'ndez R.M., Esquisabel A., Gascon A.R., Calvo M.B., Pedraz JL.: Int. J. Pharm. 169, 45 (1998).

32. Patel H.M., Ryman B.E.: FEBS Letters 62, 60 (1976).

33. Greenwood R., Al-Achi A.: Drug Dev. Ind. Pharm. 23, 221 (1997).

34. Soaresa S., Fonte P., Costaa A., Andrade J., Seabra V. et al.: Int. J. Pharm. 456, 370 (2013).
35. Romero-Calvo I., Ocón B., Martínez-Moya P., Suárez M.D., Zarzuelo A. et al.: Anal. Biochem. 401, 318 (2010).

36. Aldridge G., Podrebaraca D.M., Greenougha W.T., Weiler I.J.: J. Neurosci. Methods 172, 250 (2008).

37. Hashemi M., Kalalinia F.: Life Sci. 143, 139 (2015).

38. Ngoc P.K., Phuc P.V., Nhung T.K., Thuy D.T., Nguyet N.T.: Hum. Cell. 24, 86 (2011).

Received: 29. 12. 2017 